commenced work with this instrument as soon as the clockwork had been somewhat improved, and a photographic survey was made of the great star cluster in Perseus and published in a paper by Ball and Rambaut in the Trans. R. Irish Academy. Soon after, in the autumn of 1892 , Ball left for Cambridge and Rambaut was appointed to succeed him as Andrews professor of astronomy and Royal Astronomer of Ireland. During the next five years he continued his photographic work, but under great difficulties and with long interruptions, as the mounting, clockwork, and the dome under which the instrument was housed were all found to be useless and had to be replaced by others.

In I897 Rambaut left Dunsink to take up the post of Radcliffe Observer at Oxford. Up to that time the Radcliffe Observatory had been devoted almost altogether to meridian work, and the observations made since 1839 had been regularly published. But a vast number of observations made in the years 1774 to ${ }^{2} 8_{3} 8$ had never been prepared for publication, and Rambaut spent a good deal of time examining them. He showed that they had been carefully made and would be worth printing, but he did not succeed in obtaining the necessary means for reducing and printing these old observations. . In the meantime the Radcliffe Trustees decided to procure a first-class instrument for astronomical photography, and a tower was built in the grounds of the observatory, surmounted by a dome 32 feet in diameter. In this was, in 1902 , erected a photographic instrument by $\mathrm{Sir}$ Howard Grubb, consisting of a photographic refractor of 24 inches aperture and an I8-inch refractor for visual work. In I904 stellar parallax work was commenced, arranged according to the programme proposed by Kapteyn and in consultation with him, and this work has been continued ever since. A volume of the Radcliffe Observations published about a month ago contains the resulting parallaxes of 2400 stars in addition to full descriptions of the instrument and measuring apparatus.

More than a year ago Rambaut was attacked by illness, from which he never recovered. It was therefore very fortunate that the chief work of his life had been completed. He will be much missed by the many friends his cheerful and kindly disposition had won for him at Oxford. He leaves a widow and three sons to mourn his loss.

J. L. E. D.

\section{Dr. J. A. HARker, O.B.E., F.R.S.}

JoHn Allen HARker was born at Alston, Cumberland, on January 23, 1870 , and died at Highgate on October ro. He was thus only in his fifty-fourth year at the time of his death. The son of the Rev. John Harker, Congregational minister, he was educated at Stockport Grammar School, thence proceeding to the University of Manchester (Owens College), where he was elected Dalton scholar in chemistry in r89r and a year later Berkeley fellow in physics, taking his M.Sc. A research course at Tübingen followed, where he took the Ph.D.

Harker spent some little time in France, working with Moissan on electric furnaces, and in collaboration with Chappuis carried out in rgoo a classic comparison of the gas and platinum thermometer scales. About this time the National Physical Laboratory was being brought into being at its first home at Kew Observa- tory, and Dr. Harker was one of the little band of devoted workers whom Sir Richard Glazebrook gathered round him at the beginning of the great endeavour which resulted in the present institution at Teddington. Harker became chief of the thermometry branch of the Physics Department. His work over a period of the next ten years is largely reflected in a series of valuable papers, mostly on high temperature measurement, for which he received the F.R.S. in Igro. At the International Petroleum Congress at Vienna in I9I2 he was the delegate of the British Government. His researches with W. F. Higgins on flash-points of oils enabled him to make valuable contributions to the discussions. In association with the present writer, Dr. Harker subsequently worked on the thermionics of high-temperature furnacesa subject on which he gave a Friday evening discourse at the Royal Institution. In $x_{91} 3$ he went for several months to Eskdalemuir Observatory as temporary superintendent.

When the War broke out Harker was lent by the National Physical Laboratory to the Inventions Department of the Ministry of Munitions, and became director of the research laboratory and was responsible for the organisation of the work of the Nitrogen Products Committee. In this capacity he visited Canada and the United States in I9r8, and was on board the Cunard liner Andania when she was torpedoed off northern Ireland. On that occasion a generous act of self-sacrifice undoubtedly aggravated the ill effects of the exposure on his constitution. Harker also went on similar missions to Norway, Sweden, and France. He received the O.B.E. in recognition of his valuable War services.

After the War, Harker returned to Teddington for a brief period before setting up as a consulting engineer with Dr. J. F. Crowley in Westminster. He was a vice-president of the Faraday Society, and had served on the Council of the Physical Society. He was a prominent member of, among others, the Oxygen Committee and the Gas Cylinders Committee of the Research Department.

Harker was a man of great scientific keenness and a highly strung and very likeable personality, who will be greatly missed by his friends. He possessed a great fund of scientific reminiscences. Though never of robust physique, he did not hesitate to make frequent inroads on his reserve of nervous energy. His devotion to his War duties doubtless served to undermine his constitution, and at the end his illness was only short in duration. He married Ada, the daughter of the late Thomas Richardson, of Alston, and had two sons and three daughters. The cremation took place at Golders Green on Saturday, October I3. Among those present were Sir Richard Glazebrook and Sir Robert Robertson. Dr. T. E. Stanton represented the Royal Society and Dr. E. Griffiths and Mr. F. H. Schofield the Director and staff of the National Physical Laboratory.

G. W. C. Kaye.

WE regret to announce the following deaths :

Rev. H. J. Bidder, a curator of the Botanic Garden, Oxford, on October I9, aged seventy-six.

Mr. R. A. P. Rogers, Donegal lecturer in Trinity College, Dublin, on October I7. $_{7}$.

NO. 28 I 7 , VOL. I I 2$]$ 